\title{
3D Printing of Polycaprolactone-Polyaniline Electroactive Scaffolds for Bone Tissue Engineering
}

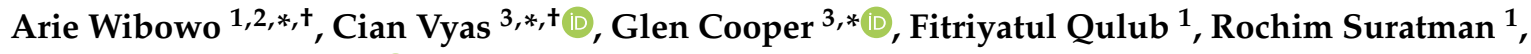 \\ Andi Isra Mahyuddin ${ }^{4}\left(\mathbb{D}\right.$, Tatacipta Dirgantara ${ }^{5}$ and Paulo Bartolo ${ }^{3}$ \\ 1 Material Science and Engineering Research Group, Faculty of Mechanical and Aerospace Engineering, \\ Institut Teknologi Bandung, Jl. Ganesha 10, Bandung 40132, Indonesia; fitriyatulqulub@gmail.com (F.Q.); \\ rochim@material.itb.ac.id (R.S.) \\ 2 Research Center for Nanoscience and Nanotechnology, Institut Teknologi Bandung, Jl. Ganesha 10, \\ Bandung 40132, Indonesia \\ 3 Department of Mechanical, Aerospace, and Civil Engineering, University of Manchester, Manchester M13 \\ 9PL, UK; paulojorge.dasilvabartolo@manchester.ac.uk \\ 4 Mechanical Design Research Group, Faculty of Mechanical and Aerospace Engineering, Institut Teknologi \\ Bandung, Jl. Ganesha 10, Bandung 40132, Indonesia; aim@ftmd.itb.ac.id \\ 5 Lightweight Structure Research Group, Faculty of Mechanical and Aerospace Engineering, Institut \\ Teknologi Bandung, Jl. Ganesha 10, Bandung 40132, Indonesia; tdirgantara@ftmd.itb.ac.id \\ * Correspondence: ariewibowo@material.itb.ac.id (A.W.); cian.vyas@manchester.ac.uk (C.V.); \\ glen.cooper@manchester.ac.uk (G.C.) \\ + equal contribution.
}

Received: 10 December 2019; Accepted: 19 January 2020; Published: 22 January 2020

\begin{abstract}
Electrostimulation and electroactive scaffolds can positively influence and guide cellular behaviour and thus has been garnering interest as a key tissue engineering strategy. The development of conducting polymers such as polyaniline enables the fabrication of conductive polymeric composite scaffolds. In this study, we report on the initial development of a polycaprolactone scaffold incorporating different weight loadings of a polyaniline microparticle filler. The scaffolds are fabricated using screw-assisted extrusion-based 3D printing and are characterised for their morphological, mechanical, conductivity, and preliminary biological properties. The conductivity of the polycaprolactone scaffolds increases with the inclusion of polyaniline. The in vitro cytocompatibility of the scaffolds was assessed using human adipose-derived stem cells to determine cell viability and proliferation up to 21 days. A cytotoxicity threshold was reached at $1 \% \mathrm{wt}$. polyaniline loading. Scaffolds with $0.1 \% \mathrm{wt}$. polyaniline showed suitable compressive strength $(6.45 \pm 0.16 \mathrm{MPa})$ and conductivity $\left(2.46 \pm 0.65 \times 10^{-4} \mathrm{~S} / \mathrm{cm}\right)$ for bone tissue engineering applications and demonstrated the highest cell viability at day $1(88 \%)$ with cytocompatibility for up to 21 days in cell culture.
\end{abstract}

Keywords: 3D printing; electroactive scaffold; polyaniline; tissue engineering

\section{Introduction}

The human body is a complex electrical system that can be most noticeably observed in the action potentials that are integral to the regulatory mechanisms in muscles and nerves. Furthermore, these biological electrical fields-apart from being crucial in the function of tissues such as the heart, muscles, and nerves-have a significant role in cellular behaviour including proliferation, morphology, signalling, migration, orientation, and regenerative processes [1-8]. Subsequently, electrical stimulation techniques and electroactive materials have been developed within tissue engineering in order to modulate cellular responses and enhance tissue regeneration. This new class of smart electroactive biomaterials that 
are able to deliver electrical, electrochemical or electromechanical stimulation directly to cells, tissue, and organs could bring a significant breakthrough in the tissue engineering field [3,5,6]. Electroactive scaffolds have already been investigated for use in neural [4,5,9], muscle [10,11], bone [12-14], and cardiac [15,16] tissue engineering applications. A key requirement is the development of biocompatible, biodegradable, and electrically conductive biomaterials. Electroactive scaffolds can be fabricated from conductive materials or prepared by the addition of conductive fillers to create a composite. These conductive materials can be classified as: carbon-based $[5,12,14,15]$, conductive polymers [1-3,6], and metallic-based [16-21].

Conductive polymers are electrically active due to a conjugated $\pi$-electron backbone allowing for delocalisation and electron mobility. They are attractive due to their facile synthesis routes; excellent electrical and optical properties; flexibility in their electrical, chemical, and physical properties; ability to be functionalised with biological moieties to improve biocompatibility and biodegradability; and wide-ranging processability [3,6-8,22-24]. A range of conductive polymers have been investigated such as polypyrrole (PPy), polyaniline (PANI), and polythiophene derivatives including poly(3,4-ethylenedioxythiophene) (PEDOT) and poly(3-hexylthiophene) (PHT) [3,6,8,23]. PANI has attracted a considerable amount of attention, especially the half oxidised emeraldine state which is highly conductive and stable, due to the ease of synthesis, low cost production, high stability, and ability to electrically switch from a conductive to a resistive state [3,4]. However, PANI has limitations such as nonbiodegradability and contradictory evidence within the literature regarding the materials biocompatibility. Numerous studies have stated that the material is cytocompatible [25-32] although it may require specific treatments to improve compatibility; however, cytotoxicity and inflammation have also been reported [22,24,33]. Therefore, it is crucial to identify the cytotoxic concentration limit of PANI within a scaffold and procedures to ensure that residual dopants and low molecular weight by-products are not present as these have been suggested to be responsible for the poor biocompatibility [26,33].

Typically, PANI is utilised in a polymeric composite to overcome its inherent brittleness after synthesis. Biodegradable and biocompatible polymers such as polycaprolactone (PCL) [34], poly(ethylene glycol) diacrylate [35], poly(lactic acid) [36], poly(D,L-lactide) [37], gelatin [38-41], and agarose [27] have been utilised to produce constructs for tissue engineering applications. Further difficulties are observed in processing due to its limited solubility in common organic solvents. PANI based electroactive scaffolds have been fabricated using various conventional fabrication routes such as in situ polymerisation/thermal induced separation [42], solution casting [10,26], hydrogel formation [27,35,39,40,42,43], and electrospinning [11,38,44-46]. However, these methods offer limited control of scaffold morphological properties such as pore size, interconnectedness, and fibre diameter. By contrast, 3D printing enables the precise control of scaffold morphology with the production of interconnected structures and a regular pore size [12-14]. 3D printing has been utilised in a range of tissue engineering applications such as cartilage [47], bone [48], vasculature [49], and nerve [50] and facilitates the fabrication of multimaterial and geometrical complex architectures that more accurately reflects that native in vivo environment [51].

Herein, we report on the initial development of a novel 3D-printed electroactive scaffold for bone tissue engineering applications. PCL scaffolds incorporating different weight concentrations of PANI was fabricated using a screw-assisted extrusion-based 3D printer. A polymeric composite was chosen to overcome the brittleness and difficulty in processing of PANI with the synthesised PANI particles incorporated through a simple method of melt compounding into the PCL matrix. Key properties of an electroactive scaffold are evaluated including scaffold morphology, conductivity, wettability, and cell viability and proliferation. This initial study focuses on physical, chemical, and electrical characterisation and provides a preliminary biocompatibility assessment for optimisation and development of a 3D-printed electroactive PCL/PANI scaffold. 


\section{Materials and Methods}

\subsection{Materials}

Aniline, ammonium peroxidisulphate (APS), hydrochloric acid ( $\mathrm{HCl})$, and acetone were purchased from Merck KGaA, Darmstadt, Germany (pro analysis (p.a.) grade). PCL was purchased from Perstorp, Warrington, UK (CAPA 6500, $\mathrm{M}_{\mathrm{w}}$ 50,000) and is biocompatible and biodegradable polymer with a melting point of $58-60{ }^{\circ} \mathrm{C}$, a glass transition temperature of $\sim-60^{\circ} \mathrm{C}$, and a density of $1.146 \mathrm{~g} / \mathrm{mL}$ at 25 ${ }^{\circ} \mathrm{C}$ and was used to prepare composite blends with PANI.

\subsection{Preparation of Polyaniline}

PANI was prepared by a chemical oxidation polymerisation method that has been previously described by Stejskal et al. [52], with slight modification. Briefly, aniline solution (9.1 mL of aniline in $250 \mathrm{~mL}$ of $1 \mathrm{M} \mathrm{HCl}$ solution) was mixed with APS solution (28.55 g APS in $250 \mathrm{~mL}$ of deionised water). After 15 min of stirring, a dark green precipitate was observed that indicated initial formation of PANI in the emeraldine salt state. The mixed solution was left without stirring for $24 \mathrm{~h}$ at $15^{\circ} \mathrm{C}$ to increase the yield and molecular weight of obtained PANI. The precipitated PANI was collected using a Whatman filter paper (No.42, $2.5 \mu \mathrm{m}$ pore size) and washed three times with $0.2 \mathrm{M} \mathrm{HCl}$ and then acetone to remove initiators, monomers and low-molecular and water-soluble oligomers [53]. Finally, the PANI powder was dried in oven for $24 \mathrm{~h}$ at $60^{\circ} \mathrm{C}$.

\subsection{Polyaniline Characterisation}

\subsubsection{Fourier-Transform Infrared Spectroscopy}

Functional groups of the produced PANI was identified by Fourier-transform infrared spectroscopy (FTIR, IRPrestige-21, Shimadzu, Kyoto, Japan) at room temperature. Samples were measured at wavenumber from 500 to $4500 \mathrm{~cm}^{-1}$. Prior to characterisation, a sample pellet was prepared by mixing PANI (10-15 mg) with potassium bromide (KBr powder) (150-250 mg), mortared, and pressed at $700 \mathrm{kN}$ for $5 \mathrm{~min}$.

\subsubsection{Powder X-ray Diffraction}

The structural phase and crystallinity of the obtained PANI at room temperature was identified by powder X-ray diffraction (XRD, D8 Advance, Bruker, Karlsruhe, Germany) that was performed at room temperature, voltage $40 \mathrm{kV}$, generator current $35 \mathrm{~mA}$ and the scanning scope of angle $(2 \theta)$ was $5-65^{\circ}$. A CuK radiation with wavelength $(\lambda)$ of $1.54 \AA$ was used.

\subsubsection{Particle Size Characterisation}

The PANI powder was wet $\left(\mathrm{dH}_{2} \mathrm{O}\right)$ vibratory ball-milled for $5 \mathrm{~h}$ to reduce the particle size, increase particle homogeneity, and improve printability. The powder was subsequently lyophilised by snap freezing in liquid nitrogen and dried for $72 \mathrm{~h}$ to recover the powder.

The particle size and volume distribution before and after wet ball-milling was quantified using a laser diffraction particle size analyser (Mastersizer 3000, Malvern Panalytical, Malvern, UK). The PANI particles were dispersed in water (refractive index $=1.33$ ). A Fraunhofer scattering and general-purpose analysis model was used. The dispersion was sonicated prior to measurement to minimise bubbles and particle agglomerates. Five measurements were performed. The particle sizes are presented as a volume distribution; Dx(10), Dx(50), and Dx(90), with 10\%,50\%, and 90\%, respectively, of the particle population lying below these size values.

\subsection{Fabrication of Polyaniline-Polycaprolactone Scaffolds}

The PANI powder (after ball milling) was mixed with the melted PCL $\left(\sim 80^{\circ} \mathrm{C}\right)$ by manual physical melt blending for a minimum of $30 \mathrm{~min}$, based on a previously described method [12-14], to ensure a 
homogenous PCL/PANI blend with PANI filler loading concentrations of $0.1 ; 1 ; 2 \%$ wt. The PCL/PANI blends were allowed to cool and then cut into small pieces to enable loading into the material chamber of the 3D printer. The composite materials are further mixed and homogenised by the rotation of the screw during extrusion in the screw-assisted extrusion 3D printing process. Mechanical mixing of PANI particles into a PCL solution has been previously described by Wu et al. [54], the process described in this study avoids the use of solvents in the preparation of the composite and is suitable for melt extrusion.

Scaffolds were fabricated using a screw-assisted extrusion-based 3D printing system (3D Discovery, regenHU, Villaz-St-Pierre, Switzerland) with a printing nozzle diameter of $330 \mu \mathrm{m}$. The scaffold architecture was designed using computer-aided design software (BioCAD, regenHU, Villaz-St-Pierre, Switzerland). The scaffold was designed with a fibre spacing of $660 \mu \mathrm{m}$, a slice thickness of $280 \mu \mathrm{m}$, a $0^{\circ} / 90^{\circ}$ lay-down pattern, and dimensions of $30 \mathrm{~mm} \times 30 \times \mathrm{mm} \times 3.36 \mathrm{~mm}$. The printing parameters used are deposition velocity of $20 \mathrm{~mm} \mathrm{~s}^{-1}$, a material chamber temperature of $90{ }^{\circ} \mathrm{C}$, an extrusion pressure of $6 \mathrm{bar}$, and a screw rotation velocity of $15 \mathrm{rpm}$ [12-14]. Scaffolds were cut to $11 \mathrm{~mm} \times 11 \mathrm{~mm} \times 3.36 \mathrm{~mm}$ for all in vitro studies.

\subsection{Scaffold Characterisation}

\subsubsection{Morphology}

Scaffold morphology was observed through scanning electron microscopy (SEM, Hitachi S3000N, Hitachi, Tokyo, Japan). Prior to imaging, scaffolds were sputter-coated with platinum for $40 \mathrm{~s}$ and imaged using a $10 \mathrm{kV}$ accelerating voltage with both top-down and cross-sectional images of the scaffolds acquired. Images were then analysed using Fiji software, to obtain measurements of pore size and fibre diameter [55].

Scaffold porosity was determined by a gravimetric method [56,57]. Each sample $(n=5)$ was weighed and the volume based on the printed dimensions before being checked with a calliper. The porosity was determined as follows:

$$
\begin{gathered}
P_{\text {scaffold }}=\frac{\text { mass }}{\text { volume }} \\
P_{\text {material }}=X_{P C L} P_{P C L}+X_{P A N I} P_{P A N I} \\
\text { Porosity }(\%)=\left(1-\frac{P_{\text {scaffold }}}{P_{\text {material }}}\right) \times 100
\end{gathered}
$$

where $P_{\text {scaffold }}=$ apparent density of the scaffold, $P_{\text {material }}=$ density of the composite material using the theoretical density of PCL (1.146 g/mL) and PANI (1.33 g/mL [52]), and $X_{P C L}$ and $X_{P A N I}$ indicate the volume fractions within the composite.

\subsubsection{Wettability}

The wettability of the PCL/PANI scaffolds was determined through the measurement of the static water contact angle at room temperature using the sessile drop and shape analysis method (KSV CAM

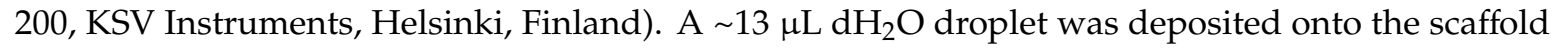
$(n=5)$ and the droplet was imaged by a high-speed camera after $50 \mathrm{~s}$ and the contact angle calculated using a Young-Laplace fit.

\subsubsection{Mechanical Properties}

The mechanical properties of scaffolds were determined at room temperature by compressive testing using a Universal Testing Machine (Tensilon RTF-1310, A\&D Company, Tokyo, Japan) at room temperature. Briefly, scaffold samples $(n=3)$ with dimension ratio of 1:1:1 were prepared and deformed by a crosshead with a load cell of $10 \mathrm{kN}$ and speed of $0.5 \mathrm{~mm} / \mathrm{min}$. The stress-strain profiles were 
obtained from the computational results of the load-displacement calculations. The compressive stress at $10 \%$ strain and the compressive Young's modulus calculated from the gradient of the initial linear elastic region are reported, methodology based on the ISO 844-2014 standard [58].

\subsubsection{Conductivity}

The electrical conductivity of the PCL/PANI scaffold samples $(n=3)$ was determined using an Alessi four-point probe at room temperature [11]. A high impedance current source $(I)$ was used to supply the current through two outer probes, whilst the voltage $(V)$ at the two inner probes was measured with an electrometer. Silver paste was added to improve the contact between probes and scaffolds. The distance between the probes $(L)$ is $1 \mathrm{~mm}$ and the conductivity $(\sigma)$ of scaffold was determined as follows:

$$
\sigma=\frac{I L}{V F}
$$

where $F$ is the correction factors for thickness and geometry of samples.

\subsection{Biological Evaluation}

\subsubsection{Cell Culture and Seeding}

Human adipose-derived stem cells (hADSCs) (STEMPRO ${ }^{\circledR}$, Invitrogen, Carlsbad, CA, USA) at passage five were used for all in vitro cell culture studies. Cells were cultured in T75 flasks with MesenPRO RS ${ }^{\mathrm{TM}}$ media (Invitrogen, Carlsbad, CA, USA), 2\% (v/v) growth supplement, $1 \%(v / v)$ glutamine, and $1 \%(v / v)$ penicillin/streptomycin under standard cell culture incubator conditions $\left(37^{\circ} \mathrm{C}\right.$, $5 \% \mathrm{CO}_{2}$, and $95 \%$ humidity). Prior to cell seeding all scaffolds were washed twice in sterile phosphate buffered saline (PBS) before sterilisation by immersion in $80 \%$ ethanol for $2 \mathrm{~h}$ after which the scaffolds were again washed twice in sterile PBS. The scaffolds were then air dried in a sterile tissue culture laminar flow hood for $12 \mathrm{~h}$. Cells were harvested using trypsinisation $(0.25 \%$ trypsin/EDTA solution, Sigma-Aldrich, St. Louis, MO, USA) and a cell suspension prepared $\left(0.33 \times 10^{6} / \mathrm{mL}\right)$. Each scaffold was then initially seeded with $150 \mu \mathrm{L}$ of cell suspension (50,000 cells per scaffold) carefully pipetted on top of the scaffold in a non-treated 24-well plate. The scaffolds were then incubated for $2 \mathrm{~h}$ under standard cell culture incubator conditions to allow cell attachment before a further $650 \mu \mathrm{L}$ of supplemented MesenPRO RS ${ }^{\mathrm{TM}}$ media was added to obtain a final volume of $800 \mu \mathrm{L}$. A non-treated well plate was used to minimise cell migration and attachment to the underlying tissue culture plastic [59]. Cell culture media was changed every three days. All cell-seeded scaffolds were transferred to a new 24-well plate on day 1 . Tissue culture plastic (TCP) was used as a control to confirm viable cell culture with the same conditions utilised as the scaffolds

\subsubsection{Cell Viability}

Viability of the cells cultured on the scaffolds was assessed at day 1 and 21 using a live/dead staining kit (Thermo Fisher Scientific, Waltham, MA, USA), which was prepared according to manufacturer's instructions. Briefly, a live/dead working solution consisting of a $2 \mu \mathrm{M}$ calcein acetoxymethyl ester (AM) (live) and $4 \mu \mathrm{M}$ ethidium homodimer-1 (dead) was prepared in prewarmed PBS. Cell culture media was aspirated, and scaffolds were washed twice in pre-warmed PBS. The live/dead staining solution was added to the scaffold and incubated for $25 \mathrm{~min}$ in a cell culture incubator. The scaffolds were then carefully inverted in the well plates using sterile forceps to allow imaging of the top surface of the scaffold. TCP was utilised as a positive control. The scaffolds were imaged using an inverted fluorescence microscope (DMI6000B, Lecia Microsystems, Wetzlar Germany) using two specific filters for green and red fluorescence. Samples $(n=4)$ were imaged and analysed using Fiji to obtain an average percentage cell viability at day 1 [55]. 


\subsubsection{Cell Proliferation}

The proliferation of hADSCs on the scaffolds was assessed using the Alamar Blue assay (also termed the Resazurin assay), which functions through the reduction of resazurin to the highly fluorescent resorufin molecule by metabolically active cells which can be related to cell proliferation. Cell proliferation was assessed on day 1, 3, 7, 14, and 21 for each sample ( $\mathrm{n}=4)$ and a TCP control [13]. Briefly, resazurin sodium salt powder (Sigma-Aldrich, St. Louis, Missouri, USA) was used to prepare a stock solution of $0.01 \%(w / v)$ in PBS, which was then filter-sterilised $(0.2 \mu \mathrm{m}$ pore size). At each time point, $80 \mu \mathrm{L}$ of the stock solution was added directly to each sample well for a final concentration of $0.001 \%(w / v)$. The samples were incubated for $4 \mathrm{~h}$ in a cell culture incubator after which $150 \mu \mathrm{L}$ of each sample was transferred to a 96-well plate. The fluorescence intensity was measured using a microplate reader (Infinite 200, Tecan, Männedorf, Switzerland) at an excitation wavelength of $540 \mathrm{~nm}$ and an emission wavelength of $590 \mathrm{~nm}$. Cell culture media containing Alamar Blue was removed and the scaffolds were washed three times in prewarmed PBS before addition of fresh cell culture media and incubation.

\subsection{Statistical Analysis}

Statistical analysis was performed using GraphPad Prism 7.01 statistical software (GraphPad Software, Inc., San Diego, CA, USA). All data is represented as mean \pm standard deviation. Comparisons of groups for porosity, wettability, cell viability and cell proliferation data were performed using one-way analysis of variance (ANOVA) and Tukey's post-hoc test. Significance levels were set at $p<0.05$ [13].

\section{Results and Discussions}

\subsection{Characterisation of Polyaniline}

The product of the oxidation polymerisation of aniline, PANI (Figure 1), can appear as three idealised oxidation states: leucoemeraldine (fully reduced state, with $n=1$ and $m=0$ ), emeraldine (half oxidation state, with $\mathrm{n}=0.5$ and $\mathrm{m}=0.5$ ), and pernigraniline (full oxidation state, with $\mathrm{n}=0$ and $\mathrm{m}=1$ ) [24]. However, only PANI in emeraldine state is able to form a highly electrically conductive PANI upon doping with acid (emeraldine salt) [24]. Therefore, it is necessary to characterise the prepared PANI powder using FTIR and XRD to confirm the successful synthesis of PANI in the conductive form.

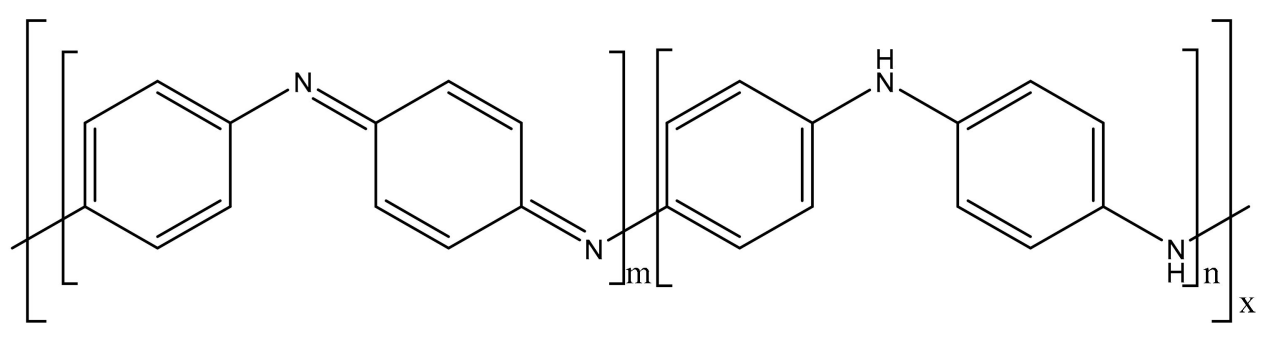

Figure 1. Chemical structure of polyaniline.

The FTIR spectra of the PANI powder shows several signature peaks of PANI emeraldine salt such as: (i) peaks at $1554 \mathrm{~cm}^{-1}$ and $1477 \mathrm{~cm}^{-1}$ belonging to the stretching vibration of quinoid (Q) and benzenoid (B) rings of PANI respectively, (ii) peak at $1301 \mathrm{~cm}^{-1}$ is correlated with delocalisation of $\pi$ electrons induced in PANI through protonation, (iii) peak at $1244 \mathrm{~cm}^{-1}$ is attributed to C-N stretch vibration in the polaron structure appearing near the secondary amine structure and also as the ribbon characteristic of the protonated form [27] (Figure 2a). Characteristic of the PANI emeraldine salt is a transmittance that continues to rise above the wavelength of $1600 \mathrm{~cm}^{-1}$; this is due to the absorption of the free charge carriers in doped polymers [60]. Further characterisation using XRD shows that 
the sample consists of two broad peaks at $2 \theta=15^{\circ}$ and $20^{\circ}$ representing the amorphous phase and a sharp peak at $25^{\circ}$ representing the crystalline phase of PANI (Figure $2 \mathrm{~b}$ ). These peaks are characteristic of PANI in the conductive form (emeraldine salt) and demonstrating the successful synthesis of the polymer $[61,62]$.
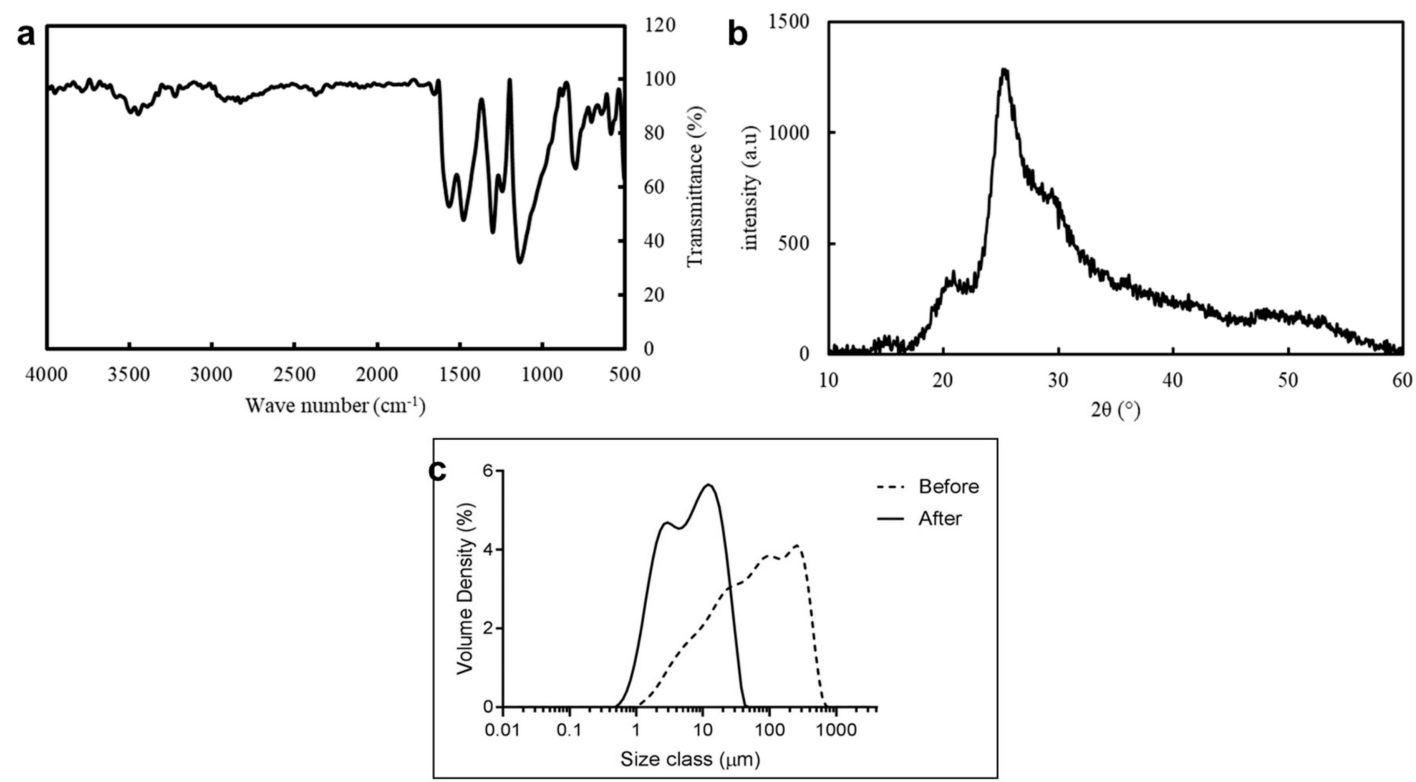

Figure 2. (a) Fourier Transform Infra-Red (FTIR) spectra and (b) Powder X-Ray Diffraction (PXRD) pattern of prepared polyaniline (PANI) powder, and (c) average particle size volume distribution of PANI before and after wet milling for $5 \mathrm{~h}$.

The mechanical ball-milling process reduced the PANI particle size and produced a more uniform particle size distribution (Figure $2 \mathrm{c}$ and Table 1). Prior to milling the PANI particles size was Dx (90) $306 \pm 37 \mu \mathrm{m}$, which is too big for printing and can potentially block the nozzle (diameter $330 \mu \mathrm{m}$ ) during extrusion. The particle size was reduced to Dx (90) $20.5 \pm 0.1 \mu \mathrm{m}$, which is suitable to allow extrusion without blockage. Furthermore, by reducing the particle size the surface area to volume ratio increases which increases the subsequent interfacial interaction and distribution of the PANI filler within the PCL polymer matrix.

Table 1. Particle size of polyaniline before and after wet ball-milling for $5 \mathrm{~h}$.

\begin{tabular}{ccc}
\hline Volume Distribution & \multicolumn{2}{c}{ Size $(\mu \mathrm{m})$} \\
\hline & Before & After \\
Dx (10) & $6.57 \pm 0.142$ & $1.66 \pm 0.004$ \\
Dx (50) & $62.4 \pm 3.3$ & $6.47 \pm 0.06$ \\
Dx (90) & $306 \pm 37$ & $20.5 \pm 0.1$ \\
\hline
\end{tabular}

\subsection{Scaffold Characterisation}

\subsubsection{Scaffold Morphology}

Scaffold morphology plays an important role in biocompatibility and cell behaviour. An appropriate morphology is needed to allow the flow and diffusion of nutrients and gases throughout the structure whilst supporting cell attachment, migration, and proliferation during the maturation phase. Preliminary observation using stereomicrograph showed that the scaffolds gradually turned darker with addition of PANI (Figure S1) and the microparticles could be observed within the polymer matrix (Figure S2). The average particle size of PANI observed through the stereomicrographs is $19.9 \pm 5.5 \mu \mathrm{m}$ which is comparable with the particle size of PANI observed after 
ball-milling $(20.5 \pm 0.1 \mu \mathrm{m})$. This suggests that the PANI particles are well distributed in the PCL matrix and no particle agglomeration occurred during material preparation and 3D printing. FTIR was performed on the PCL/PANI scaffolds and no new peaks were observed confirming that only physical blending occurred, and no new chemical bonds were formed (Figure S3). Further morphological observations of the 3D-printed PCL/PANI scaffolds was performed using SEM and the pore size and fibre diameter quantified (Figure 3 and Table 2). The scaffolds at all concentrations of PANI have a uniform geometry, regular pore size, circular cross-sections of the printed fibres, and are interconnected throughout, which demonstrates successful 3D printing and displays the advantages of 3D printing over conventional fabrication techniques.
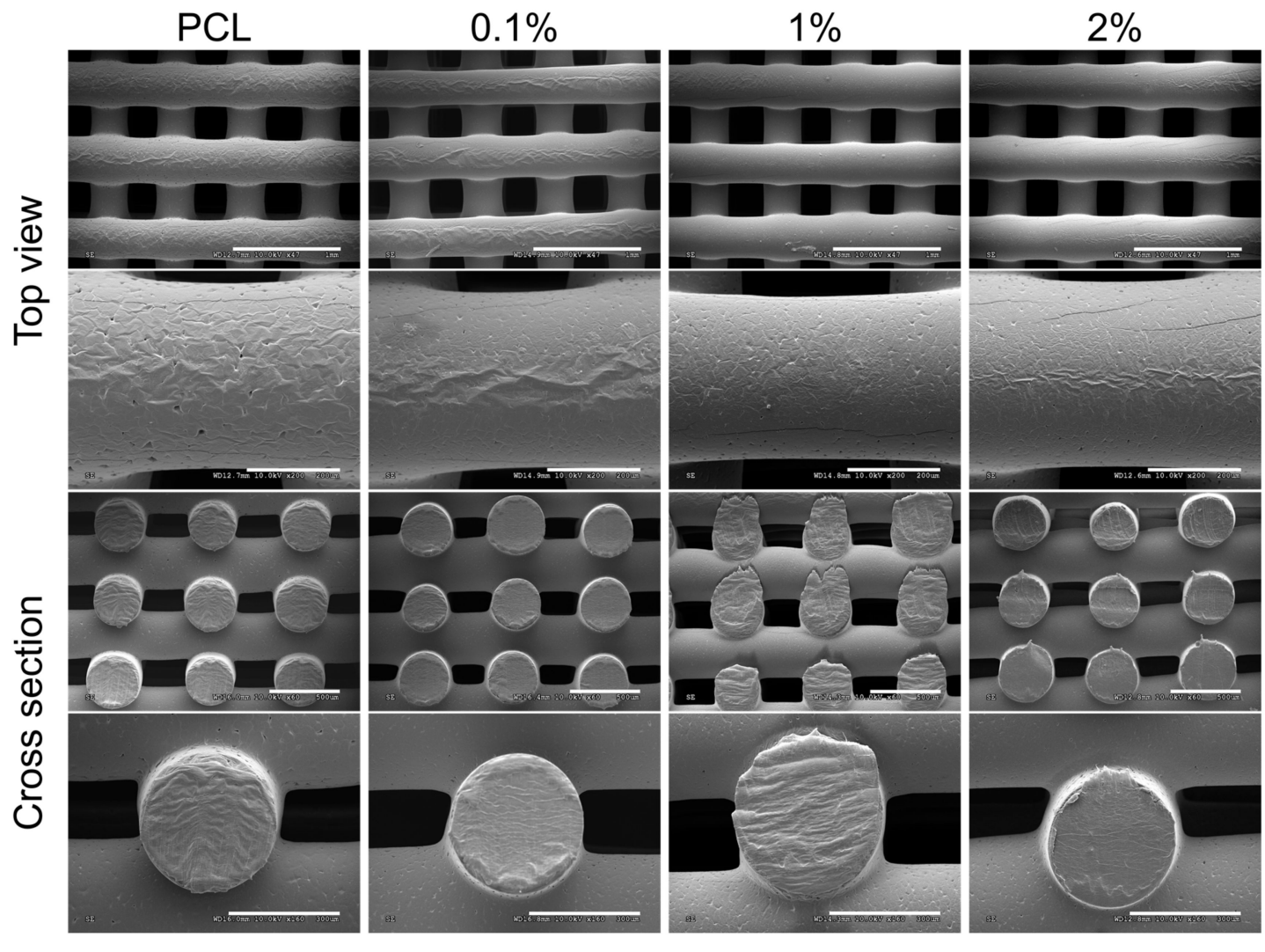

Figure 3. Scanning electron microscope (SEM) images of polycaprolactone (PCL)/polyaniline (PANI) scaffolds with different PANI filler loading $(0.1 ; 1$ and $2 \% \mathrm{wt}$.). Scale bars from top to bottom: $1 \mathrm{~mm}$, $200 \mu \mathrm{m}, 500 \mu \mathrm{m}$, and $300 \mu \mathrm{m}$.

Table 2. Summary of average fibre diameter and pore size of PCL/PANI scaffolds based on SEM and porosity determined gravimetrically $(n=5)$.

\begin{tabular}{cccc}
\hline PANI Concentration $(\%$ wt.) & Fibre Diameter $(\boldsymbol{\mu m})$ & Pore Size $(\boldsymbol{\mu m})$ & Porosity $(\%)$ \\
\hline 0 & $379.1 \pm 24.1$ & $314.6 \pm 23.8$ & $49.51 \pm 0.740$ \\
0.1 & $364.8 \pm 22.9$ & $305.9 \pm 35.5$ & $48.16 \pm 1.071$ \\
1 & $379.3 \pm 21.2$ & $295.5 \pm 34.5$ & $48.01 \pm 0.457$ \\
2 & $382.5 \pm 22.2$ & $290.9 \pm 28.6$ & $44.69 \pm 1.602$ \\
\hline
\end{tabular}

The approximate pore size and fibre diameter of the 3D-printed scaffolds are $300 \mu \mathrm{m}$ and $375 \mu \mathrm{m}$, respectively. No significant different in pore size and fibre diameter is observed between the different samples even as the concentration of the PANI filler increases. A pore size of $\sim 300 \mu \mathrm{m}$ is beneficial for facilitating diffusion of nutrition, allowing cell migration, accelerating cell proliferation, and enabling vascularisation $[63,64]$. The scaffolds have a porosity of between $44 \%-50 \%$ with a slight decrease in porosity with increasing PANI loading. This is consistent with the larger fibre diameter and smaller 
pore size observed as PANI loading increases and the higher density of PANI. A high porosity in scaffolds is necessary to allow diffusion and release of biological molecules and nutrients throughout the entire structure that supports appropriate cell behaviour [57,65]. The fabricated PCL/PANI scaffolds have a suitable morphology to enable nutrient diffusion, cell proliferation and migration.

\subsubsection{Wettability}

Scaffold wettability is an important parameter in tissue engineering as it influences the interaction of biological molecules (e.g., protein adsorption) and cells with the biomaterial surface and subsequently has a major role in biocompatibility [66-68]. Therefore, the determination of the wettability of the scaffolds was performed by water contact angle measurement (Figure 4).

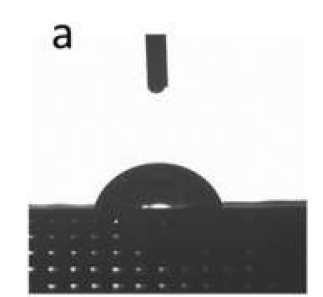

C

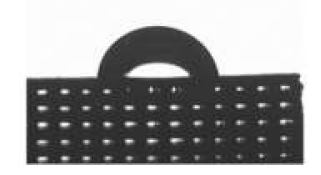

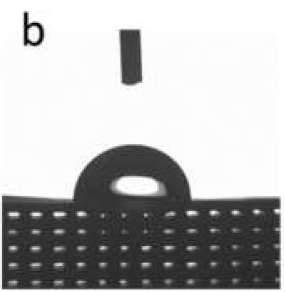

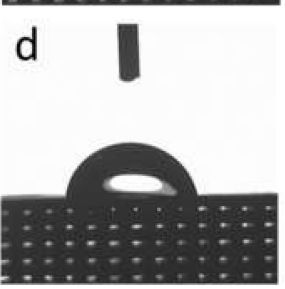

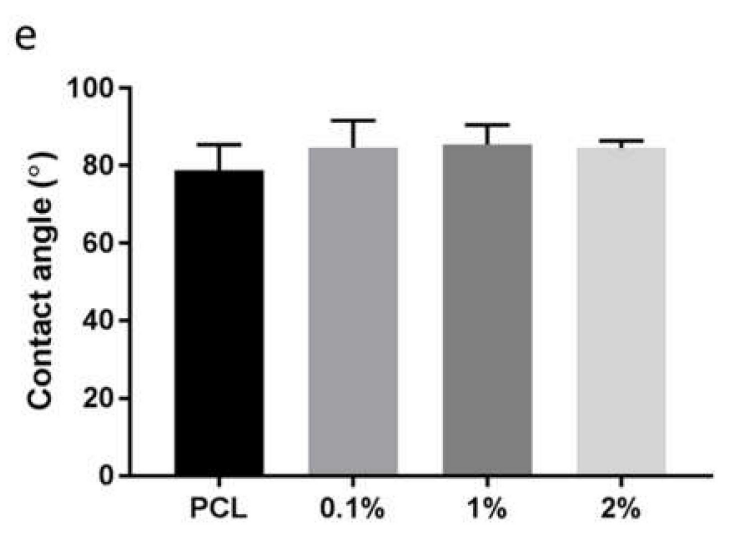

Figure 4. Contact angle images (50 s) of the water droplet on the scaffold with a) PCL, b) $0.1 \%, \mathbf{c}) 1 \%$ and d) $2 \%$ wt. PANI. e) Contact angle measurements of the scaffolds.

Material surfaces with a contact angle below $90^{\circ}$ are considered hydrophilic, whilst above $90^{\circ}$ is considered hydrophobic. Based on the contact angle measurements, a trend is observed with the scaffolds becoming slightly more hydrophobic with increasing concentration of PANI, although not significantly. These results contradict results within the literature that addition of PANI to PCL increases hydrophilicity due to the presence of the $-\mathrm{NH}_{2}$ functional group or $\mathrm{HCl}$ doping $[69,70]$. These results could be obtained if PCL and PANI are mixed in a solution phase so that the PANI polymer chain is evenly distributed throughout the matrix and surface. However, when PCL and PANI are mixed in different phases such as in physical melt blending there is the possibility that majority of the water interacts with PCL phase, which is hydrophobic. Thus, the addition of PANI powder into the PCL matrix may not provide a significant hydrophilic effect, which is also observed by Wu et al. who shows that PANI reduces the hydrophobicity of a PCL electrospun mesh but not significantly and has little effect at higher loadings [54]. Although other factors maybe influencing the slight increase in contact angle such as changes in surface roughness of the scaffold. The SEM images of the scaffold surface show a slightly smoother surface with inclusion of PANI with less pits compared to the PCL scaffold (Figure 3). The inclusion of particles effects the material rheology and extrusion flow properties, typically imparting shear thinning behaviour, which can influence the final extruded fibre and surface roughness [71]. Furthermore, the hemispherical and semi-round rod theory of close-packed models predicts that a rougher surface leads to a lower contact angle [72]. Based on this theory, it may be plausible that the addition of PANI results in a smoother surface thus higher hydrophobicity, however, further investigation is required to ascertain this.

\subsubsection{Mechanical Properties}

A major drawback of polymeric based scaffolds for load-bearing applications such as bone tissue engineering is their relatively poor mechanical properties. Thus, addition of fillers can be utilised to 
increase the mechanical properties of the scaffolds. The compressive mechanical properties of the scaffold were determined through uniaxial compression. The scaffolds show mechanical behaviour and stress-strain profiles typical of a cellular solid with an initial linear elastic region, a plastic yielding plateau region, and finally, densification (Figure 5) [73].

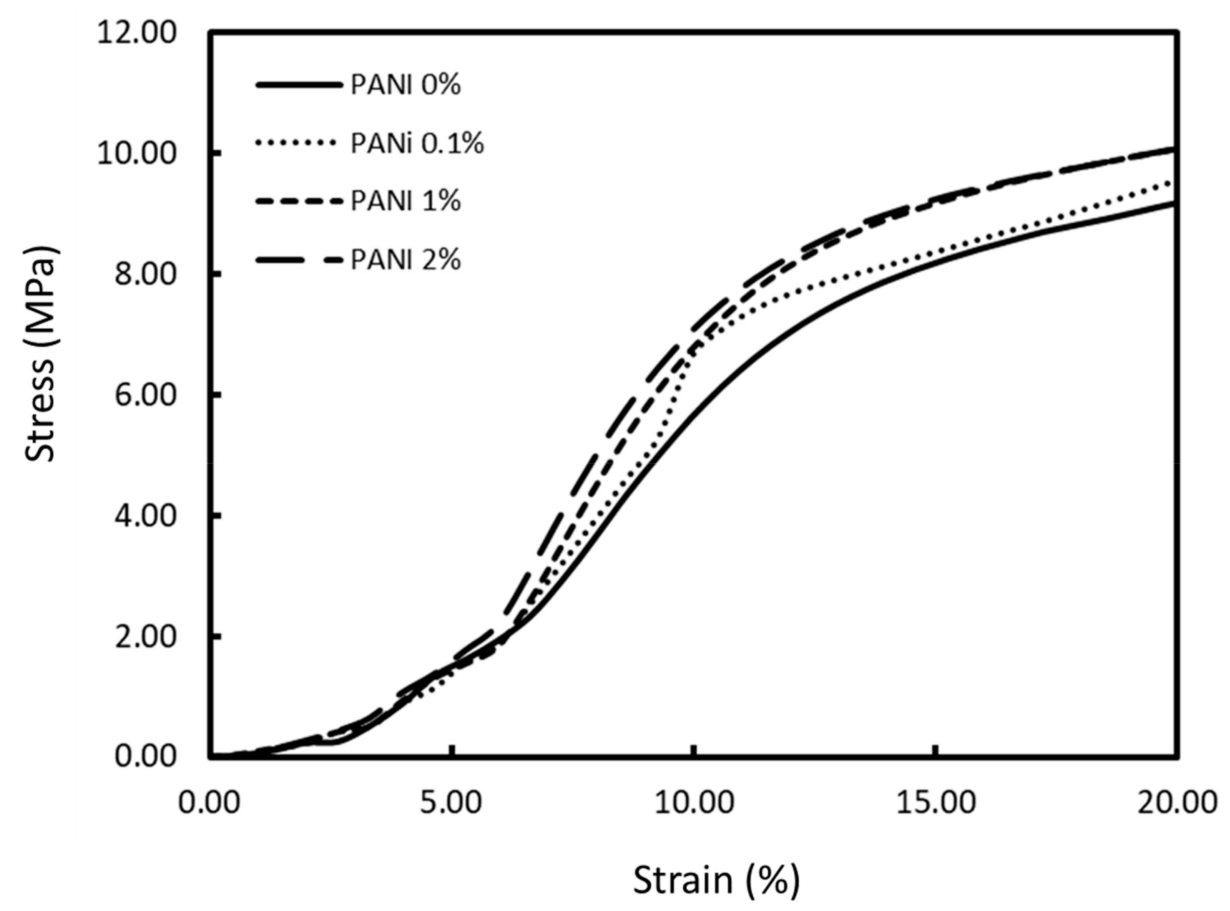

Figure 5. Representative compressive stress-strain curves of the 3D-printed PCL/PANI scaffolds as a function of PANI concentration.

The compressive Young's modulus and strength was calculated based on ISO 844-2014 standard for testing of rigid cellular plastics with the modulus determined as the gradient at the linear elastic region and compressive strength defined at $10 \%$ strain (Table 3 ). The increasing concentration of PANI as filler in the PCL matrix leads to an increase in the compressive strength of the scaffolds. The scaffold with the highest compressive strength was $2 \%$ wt. PANI, which is approximately $28 \%$ stiffer than PCL alone. The mechanical properties of these scaffolds are within the lower range of human cancellous bone, which has wide range of compressive strength (1-12 MPa) and Young's modulus (100-5000 $\mathrm{MPa})$, dependent on anatomical location, age, and measurement technique [74,75]. The scaffolds may have mechanical suitability for specific cancellous bone applications.

Table 3. The compressive Young's modulus and compressive strength at $10 \%$ strain of the PCL/PANI scaffolds.

\begin{tabular}{ccc}
\hline PANI Concentration (\% wt.) & Compressive Young's Modulus (MPa) & Compressive Strength (MPa) \\
\hline 0 & $64.43 \pm 3.97$ & $5.53 \pm 0.08$ \\
0.1 & $68.35 \pm 5.15$ & $6.45 \pm 0.16$ \\
1 & $73.83 \pm 4.22$ & $6.83 \pm 0.10$ \\
2 & $82.61 \pm 6.94$ & $7.38 \pm 0.35$ \\
\hline
\end{tabular}

\subsubsection{Conductivity}

Scaffold conductivity is a major parameter for a successful electroactive scaffold. A low conductivity biodegradable polymer, such as PCL, requires the addition of a conductive filler (PANI in this study) to sufficiently increase the scaffold conductivity so it may be utilised for electrical stimulation in tissue engineering applications. The conductivity of the scaffolds was measured using the four-point probe 
method (Table 4). The conductivity of PCL was unquantifiable; Chen et al. also used a four-point probe, and likewise showed undetectable conductivity [11]. However, PCL has been shown to be approximately $1.1 \times 10^{-11} \mathrm{~S} / \mathrm{cm}$ at $20 \pm 2{ }^{\circ} \mathrm{C}$ [54]. The inclusion of $0.1 \% \mathrm{wt}$. PANI significantly increased the conductivity $\left(2.46 \pm 0.85 \times 10^{-4} \mathrm{~S} / \mathrm{cm}\right)$ of the scaffold compared to PCL alone. Increasing the PANI filler concentration further only gave a small increase in conductivity. This may be due to the critical filler concentration-the percolation threshold-being reached and a continuous electrical network formed which overcomes the insulating properties of the PCL matrix. Further investigation at lower and higher concentrations is required to determine the specific percolation threshold within this specific composite. The conductivity of PCL/PANI scaffolds is within the region of conductivity observed in cancellous $\left(1.6-2.0 \times 10^{-3} \mathrm{~S} / \mathrm{cm}\right)$ and cortical bone $\left(5.8-6.3 \times 10^{-4} \mathrm{~S} / \mathrm{cm}\right)$ [76]. The electrical conductivity could be further improved by using a solvent mixing method to improve the particle distribution or increasing the aspect ratio of the PANI to form fibres, thus improving the electrical network [34]. Furthermore, the long-term conductivity profile of the scaffolds in aqueous physiological conditions still needs to be assessed to determine the rate of de-doping of the PANI and the subsequent decrease in conductivity.

Table 4. Conductivity of the PCL/PANI scaffolds.

\begin{tabular}{cc}
\hline PANI Concentration (\% wt.) & Conductivity $\left(\mathbf{1 0}^{-\mathbf{4}} \mathbf{S} / \mathbf{c m}\right)$ \\
\hline 0.1 & $2.46 \pm 0.85$ \\
1 & $2.53 \pm 0.65$ \\
2 & $2.84 \pm 0.51$ \\
\hline
\end{tabular}

The addition of PANI improves the conductivity of the printed scaffold and is potentially suitable for applying electrical stimulation to guide cell behaviour. By improving the conductivity of the scaffold, the applied voltage or current could be reduced, but could still achieve the desired effect in the target cell or tissue.

\subsection{Cell Viability and Proliferation}

The 3D-printed PCL/PANI scaffolds have been initially biologically evaluated by assessing the cell viability and proliferation of seeded hADSCs and to determine the maximum PANI particle loading cytotoxicity threshold. As previously discussed, the cytocompatibility of PANI has been shown to be mostly positive but studies have demonstrated significant cytotoxicity. This contradiction needs further evaluation and the determination of a cytotoxicity threshold or if other factors are implicated, such as toxic by-products.

The cell viability of the PCL/PANI scaffolds was assessed using a Live/Dead assay after 1 and 21 days in cell culture (Figure 6). The results demonstrate that at day 1 , the PCL, $0.1 \%$ and $1 \%$ wt. PANI scaffolds have high cell viability with only a few dead cells observed and percentage viability of approximately $75 \%, 88 \%$, and $75 \%$, respectively. The $2 \%$ wt. PANI scaffold showed a clear cytotoxic effect with only a few live cells present. Higher concentrations of PANI seem to generate a cytotoxic response in hADSCs. Noticeably, the cell morphology on the 0.1 and $1 \% \mathrm{wt}$. PANI scaffolds are more spread out and have larger cell bodies compared to pure PCL, which may be a result of changes in the surface chemistry and roughness of the scaffolds. This warrants further investigation to understand the biomaterial-cell interactions influencing cell adhesion and spreading. Cell viability by day 21 demonstrates that only the PCL and $0.1 \%$ wt. scaffolds support viable cells. The scaffolds show only a few dead cells most likely due to the scaffolds supporting a large amount of cell proliferation and the cells reaching confluency. The $1 \%$ and $2 \%$ wt. scaffolds show no viable cells. 

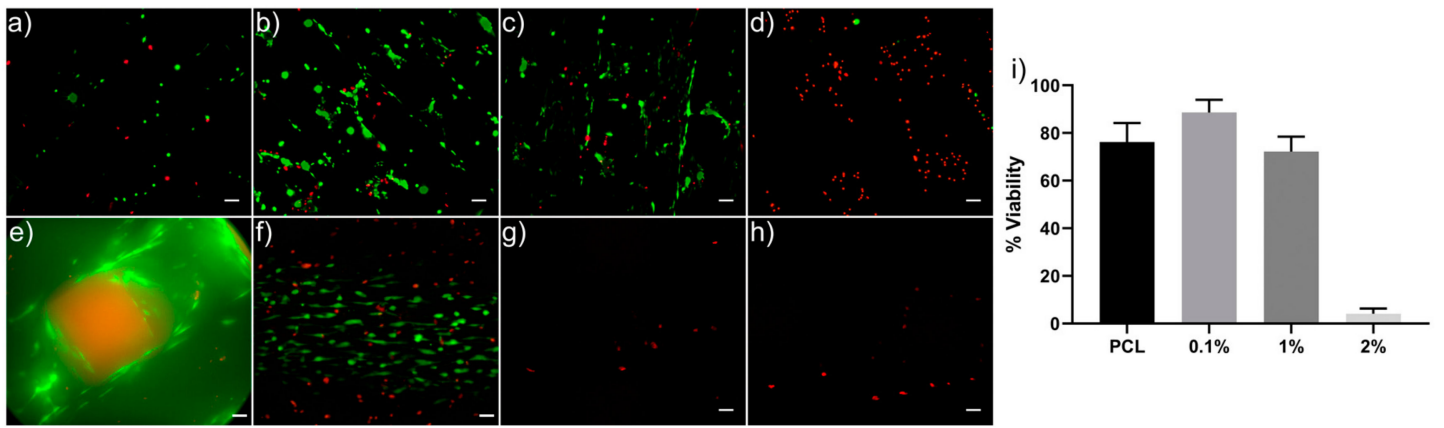

Figure 6. Cell viability of the PCL/PANI scaffolds. Live (green) and dead (red) staining of the hADSCs after 1 day of cell culture (a) PCL, (b) $0.1 \%$, (c) 1\%, and (d) 2\% wt. PANI (scale bar = $100 \mu \mathrm{m}$ ); and 21 days (e) PCL, (f) $0.1 \%$, (g) $1 \%$, and (h) $2 \%$ wt. PANI (scale bar $=50 \mu \mathrm{m}$ ). (i) Percentage cell viability after 1 day in cell culture.

Cell proliferation of hADSCs on the PCL/PANI scaffolds was evaluated by the Alamar Blue assay up to 21 days (Figure 7). All scaffolds show successful cell attachment on day 1 with comparable fluorescence intensities to the TCP control. The PCL and $0.1 \%$ wt. PANI scaffolds supported cell proliferation for up to 14 days with the $0.1 \%$ wt. PANI scaffold have the highest cell proliferation by day 14. This suggests that the presence of PANI at low percentage weight-loading increases cell proliferation. At day 21, a slight decrease in fluorescence intensity is observed in the $0.1 \% \mathrm{wt}$. PANI scaffold whilst proliferation increases in PCL only. However, a similar decrease in fluorescence intensity was also observed on the TCP. This phenomenon is most likely due to cell confluence being reached after 21 days of cell culture and the metabolic activity of the cells decreasing thus a decrease in fluorescence intensity, as indicated by the Alamar Blue assay. Furthermore, this indicates that a confluent cell state was potentially reached earlier in the $0.1 \%$ wt. PANI scaffold than the PCL only scaffold.

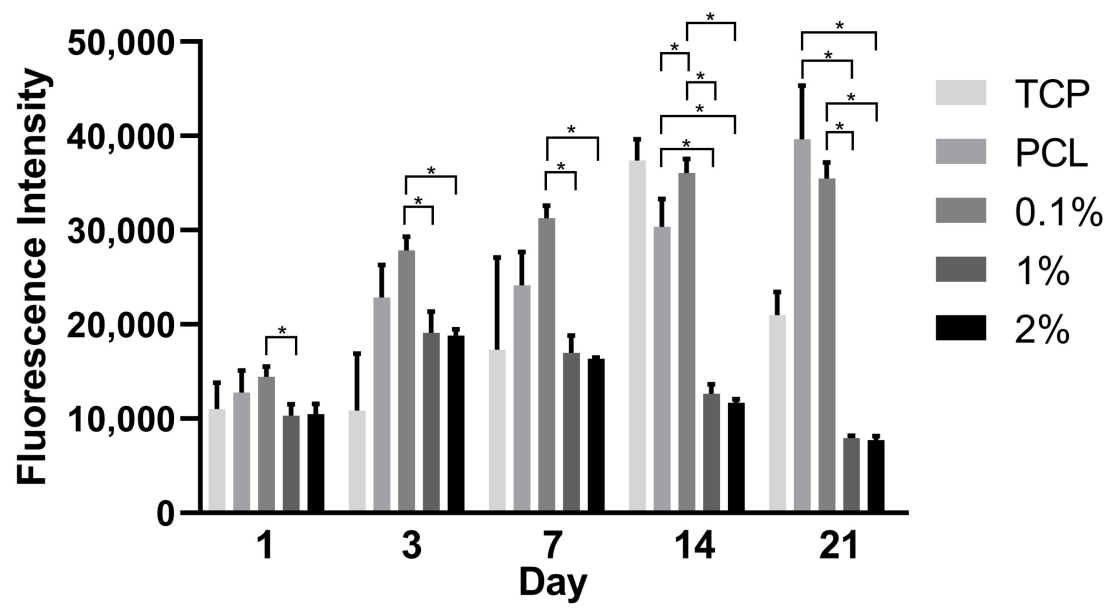

Figure 7. Proliferation of human adipose derived stem cells (hADSCs) on the TCP and PCL/PANI scaffolds measured using the Alamar Blue assay at day 1, 3, 7, 14, and 21. Results indicate significant difference in proliferation between samples $\left({ }^{*} p<0.05\right)$.

However, both 1 and $2 \%$ wt. PANI scaffolds showed only an increase in fluorescence intensity until day 3 before decreasing, indicating that the scaffolds at these levels of PANI loading are cytotoxic. This cytotoxicity is seen immediately at the higher concentration as indicated by the cell viability imaging but is delayed in the $1 \%$ wt. scaffold, which at day 1 has high cell viability (Figure 6). The cytotoxicity may be caused by the release of dopant residues or low molecular weight by-products generated during PANI synthesis and at higher PANI concentrations is mostly toxic with $24 \mathrm{~h}$, but at lower concentrations requires time to leach out into the cell culture media before reaching their 
toxic level and causing a cytotoxic effect. Similar findings have shown that the reaction residues and by-products are a likely cause for cytotoxicity [26,32]. Furthermore, PANI dopants have been demonstrated to leach out at physiological $\mathrm{pH}$ [77]. Changes in $\mathrm{pH}$, weight loss, and chloride ion concentration in the PCL/PANI scaffolds during incubation in PBS for up to 14 days are demonstrated in Table S1, Table S2 and Figure S4, respectively. Small changes in the pH of PBS solution and the weight of the scaffold are observed after 14 days. The addition of PANI does not significantly alter the rate of degradation between samples within the timeframe of this study. The chloride ion concentration in the $0.1 \%$ wt. PANI scaffold and the $1 \%$ wt. PANI scaffold at day 1 and day 14 are relatively similar. However, the chloride ion concentration significantly increases in the $2 \%$ wt. PANI scaffold which may have a role in the cytotoxicity observed in these samples. Nonetheless, the trend of $\mathrm{pH}$ and chloride ion concentration are not consistent with cell proliferation results, suggesting that $\mathrm{pH}$ or leaching of chloride ion is not the main cause of decreasing cytocompatibility as PANI concentration increases. Humpolicek et. al. found that biocompatibility of PANI can be increased by repeated deprotonation and reprotonation cycles, indicating that the release of by-products of the polymer synthesis is the main cause of cytotoxicity of PANI rather than PANI itself [32]. This study assessed cell proliferation up to 21 days, which is longer than other studies [26,32,54,78] and may allow the build-up of cytotoxic effects that might not be observed during shorter studies. Therefore, further investigation is required to ascertain the role of dopant or by-product release on biocompatibility and additional purification and washing steps of the samples may be required. Furthermore, secondary biological effects of PANI as a nonbiodegradable material, to the authors knowledge, is not known and should be investigated in further studies before PCL/PANI scaffolds can be determined as fully viable.

\section{Conclusions}

This study demonstrates - for the first time - the fabrication of a 3D-printed electroactive PCL/PANI composite scaffold and its initial development and characterisation for tissue engineering applications. The synthesis of the conductive emeraldine PANI was successful and the powder was ball milled to a suitable size for extrusion-based 3D printing and melt-blending with PCL. The scaffold wettability and mechanical properties are similar to PCL alone, however, the electrical conductivity is significantly higher, demonstrating its suitability as an electroactive scaffold. A preliminary biological assessment of scaffold cytocompatibility was conducted with hADSCs, which showed a cytotoxic effect at higher concentrations ( 1 and $2 \%$ wt.) of PANI after 3 days of cell culture, while the $0.1 \% \mathrm{wt}$. PANI scaffolds were cytocompatible and had comparable cell proliferation to PCL-only scaffolds for up to 21 days. Scaffolds with $0.1 \%$ wt. PANI show cytocompatibility and are conductive. Further investigation is required to elucidate the mechanism of cytotoxicity and improve the conductivity of the scaffolds. However, this is a promising step in the initial development and optimisation of a 3D-printed electroactive polymeric composite scaffold for bone tissue engineering applications and allows further investigation within the field.

Supplementary Materials: The following are available online at http://www.mdpi.com/1996-1944/13/3/512/s1, Figure S1. Optical microscopy images of the 3D-printed PCL/PANI scaffolds: a) PCL, b) $0.1 \%$, c) $1.0 \%$ and d) $2.0 \%$ wt. PANI (scale bar $=1 \mathrm{~mm}$ ); Figure S2. Optical microscopy of scaffold with 0 and $0.1 \mathrm{wt} . \%$ PANI scaffold highlighting the observable inclusion of the PANI microparticles within the PCL matrix (Scale bar $=0.2 \mathrm{~mm}$ ); Figure S3. FTIR spectra of PANI, PCL and PANI/PCL scaffold. Suggesting that no new bonds are formed between PCL-PANI in the composite scaffold, this implies that only physical blending of PANI and PCL occurred in the PCL/PANI scaffold; Figure S4. Determination of chloride ion concentration in phosphate buffered saline (PBS) solution after immersion of PCL/PANI scaffolds for 1 and 14 days; Table S1. pH observation of phosphate buffered saline solution after immersion of scaffolds as a function of immersion time; Table S2. Scaffold weight loss during incubation in PBS solution for up to 15 days.

Author Contributions: Conceptualization, A.W., C.V. and P.B.; Data curation, C.V.; Formal analysis, C.V. and F.Q.; Funding acquisition, A.W., R.S., A.I.M. and T.D.; Investigation, A.W., C.V., G.C. and F.Q.; Methodology, A.W., C.V. and G.C.; Project administration, A.W.; Resources, A.W.; Supervision, A.W. and P.B.; Validation, A.W.; Writing-original draft, A.W., C.V. and G.C.; Writing-review \& editing, C.V., G.C., R.S., A.I.M., T.D. and P.B. All authors have read and agreed to the published version of the manuscript. 
Acknowledgments: The authors wish to acknowledge the funding provided by the Indonesian Ministry for Research, Technology and Higher Education Overseas Collaboration Research Fund (No. 436.11/I1.C08/PL-DIKTI/2018) and the United Kingdom's Engineering and Physical Sciences Research Council (EPSRC) and Medical Research Council (MRC) Centre for Doctoral Training in Regenerative Medicine (EP/L014904/1). The authors would like to thank the World Class University program, Institut Teknologi Bandung, for their support; the Research Centre for Nanoscience and Nanotechnology, Institut Teknologi Bandung, for utilisation of their characterisation facilities; Lia Asri for fruitful discussion; Andrew Wallwork, University of Manchester, for his expertise in ball milling and particle size characterisation; and the Department of Mechanical, Aerospace and Civil Engineering, University of Manchester, for hosting visiting researchers.

Conflicts of Interest: The authors declare no conflicts of interest.

\section{References}

1. Hardy, J.G.; Lee, J.Y.; Schmidt, C.E. Biomimetic conducting polymer-based tissue scaffolds. Curr. Opin. Biotechnol. 2013, 24, 847-854. [CrossRef] [PubMed]

2. Lee, J.Y. Electrically Conducting Polymer-Based Nanofibrous Scaffolds for Tissue Engineering Applications. Polym. Rev. 2013, 53, 443-459. [CrossRef]

3. Balint, R.; Cassidy, N.J.; Cartmell, S.H. Conductive polymers: Towards a smart biomaterial for tissue engineering. Acta Biomater. 2014, 10, 2341-2353. [CrossRef] [PubMed]

4. Ghasemi-Mobarakeh, L.; Prabhakaran, M.P.; Morshed, M.; Nasr-Esfahani, M.H.; Baharvand, H.; Kiani, S.; Al-Deyab, S.; Ramakrishna, S. Application of conductive polymers, scaffolds and electrical stimulation for nerve tissue engineering. J. Tissue Eng. Regen. Med. 2011, 5, e17-e35. [CrossRef] [PubMed]

5. Zhang, Z.; Klausen, L.H.; Chen, M.; Dong, M. Electroactive Scaffolds for Neurogenesis and Myogenesis: Graphene-Based Nanomaterials. Small 2018, 14, 1801983. [CrossRef] [PubMed]

6. Palza, H.; Zapata, A.P.; Angulo-Pineda, C. Electroactive Smart Polymers for Biomedical Applications. Materials 2019, 12, 277. [CrossRef] [PubMed]

7. Guo, B.; Glavas, L.; Albertsson, A.-C. Biodegradable and electrically conducting polymers for biomedical applications. Prog. Polym. Sci. 2013, 38, 1263-1286. [CrossRef]

8. Kaur, G.; Adhikari, R.; Cass, P.; Bown, M.; Gunatillake, P. Electrically conductive polymers and composites for biomedical applications. RSC Adv. 2015, 5, 37553-37567. [CrossRef]

9. Sensharma, P.; Madhumathi, G.; Jayant, R.D.; Jaiswal, A.K. Biomaterials and cells for neural tissue engineering: Current choices. Mater. Sci. Eng. C 2017, 77, 1302-1315. [CrossRef]

10. Chen, J.; Dong, R.; Ge, J.; Guo, B.; Ma, P.X. Biocompatible, Biodegradable, and Electroactive Polyurethane-Urea Elastomers with Tunable Hydrophilicity for Skeletal Muscle Tissue Engineering. ACS Appl. Mater. Interfaces 2015, 7, 28273-28285. [CrossRef]

11. Chen, M.-C.; Sun, Y.-C.; Chen, Y.-H. Electrically conductive nanofibers with highly oriented structures and their potential application in skeletal muscle tissue engineering. Acta Biomater. 2013, 9, 5562-5572. [CrossRef] [PubMed]

12. Wang, W.; Passarini, J.R., Jr.; Nalesso, P.R.L.; Musson, D.; Cornish, J.; Mendonça, F.; Caetano, G.F.; Bárrtolo, F. Engineered 3D printed poly( $\varepsilon$-caprolactone)/graphene scaffolds for bone tissue engineering. Mater. Sci. Eng. C 2019, 100, 759-770. [CrossRef] [PubMed]

13. Wang, W.; Caetano, G.; Ambler, S.W.; Blaker, J.J.; Frade, A.M.; Mandal, P.; Diver, C.; Bártolo, P. Enhancing the Hydrophilicity and Cell Attachment of 3D Printed PCL/Graphene Scaffolds for Bone Tissue Engineering. Materials 2016, 9, 992. [CrossRef] [PubMed]

14. Huang, B.; Vyas, C.; Roberts, I.; Poutrel, Q.-A.; Chiang, W.-H.; Blaker, J.J.; Huang, Z.; Bártolo, P. Fabrication and characterisation of 3D printed MWCNT composite porous scaffolds for bone regeneration. Mater. Sci. Eng. C 2019, 98, 266-278. [CrossRef]

15. Martins, A.M.; Eng, G.; Caridade, S.G.; Mano, J.F.; Reis, R.L.; Vunjak-Novakovic, G. Electrically Conductive Chitosan/Carbon Scaffolds for Cardiac Tissue Engineering. Biomacromolecules 2014, 15, 635-643. [CrossRef]

16. Wickham, A.; Vagin, M.; Khalaf, H.; Bertazzo, S.; Hodder, P.; Dånmark, S. Electroactive biomimetic collagen-silver nanowire composite scaffolds. Nanoscale 2016, 8, 14146-14155. [CrossRef]

17. Baei, P.; Jalili-Firoozinezhad, S.; Rajabi-Zeleti, S.; Tafazzoli-Shadpour, M.; Baharvand, H.; Aghdami, N. Electrically conductive gold nanoparticle-chitosan thermosensitive hydrogels for cardiac tissue engineering. Mater. Sci. Eng. C 2016, 63, 131-141. [CrossRef] 
18. Nguyen, H.-L.; Jo, K.Y.; Cha, M.; Cha, J.Y.; Yoon, K.D.; Sanandiya, D.N.; Prajatelistia, E.; Oh, D.X.; Hwang, D.S. Mussel-Inspired Anisotropic Nanocellulose and Silver Nanoparticle Composite with Improved Mechanical Properties, Electrical Conductivity and Antibacterial Activity. Polymers 2016, 8, 102. [CrossRef]

19. Aydemir Sezer, U.; Ozturk, K.; Aru, B.; Yanıkkaya Demirel, G.; Sezer, S.; Bozkurt, M.R. Zero valent zinc nanoparticles promote neuroglial cell proliferation: A biodegradable and conductive filler candidate for nerve regeneration. J. Mater. Sci. Mater. Med. 2016, 28, 19. [CrossRef]

20. Baranes, K.; Shevach, M.; Shefi, O.; Dvir, T. Gold Nanoparticle-Decorated Scaffolds Promote Neuronal Differentiation and Maturation. Nano Lett. 2016, 16, 2916-2920. [CrossRef]

21. Ravichandran, R.; Sridhar, R.; Venugopal, J.R.; Sundarrajan, S.; Mukherjee, S.; Ramakrishna, S. Gold Nanoparticle Loaded Hybrid Nanofibers for Cardiogenic Differentiation of Stem Cells for Infarcted Myocardium Regeneration. Macromol. Biosci. 2014, 14, 515-525. [CrossRef] [PubMed]

22. Guimard, N.K.; Gomez, N.; Schmidt, C.E. Conducting polymers in biomedical engineering. Prog. Polym. Sci. 2007, 32, 876-921. [CrossRef]

23. Guo, B.; Ma, P.X. Conducting Polymers for Tissue Engineering. Biomacromolecules 2018, 19, $1764-1782$. [CrossRef] [PubMed]

24. Gajendiran, M.; Choi, J.; Kim, S.-J.; Kim, K.; Shin, H.; Koo, H.-J.; Kim, K. Conductive biomaterials for tissue engineering applications. J. Ind. Eng. Chem. 2017, 51, 12-26. [CrossRef]

25. Mattioli-Belmonte, M.; Giavaresi, G.; Biagini, G.; Virgili, L.; Giacomini, M.; Fini, M.; Giantomassi, F.; Natali, D.; Torricelli, P.; Giardino, R. Tailoring Biomaterial Compatibility: In Vivo Tissue Response versus in Vitro Cell Behavior. Int. J. Artif. Organs. 2003, 26, 1077-1085. [CrossRef] [PubMed]

26. Bidez, P.R.; Li, S.; MacDiarmid, A.G.; Venancio, E.C.; Wei, Y.; Lelkes, P.I. Polyaniline, an electroactive polymer, supports adhesion and proliferation of cardiac myoblasts. J. Biomater. Sci. Polym. Ed. 2006, 17, 199-212. [CrossRef]

27. Zarrintaj, P.; Rezaeian, I.; Bakhshandeh, B.; Heshmatian, B.; Ganjali, M.R. Bio—onductive Scaffold Based on Agarose-Polyaniline for Tissue Engineering. J. Skin Stem Cell 2017, 4, e67394.

28. Ghasemi-Mobarakeh, L.; Prabhakaran, M.P.; Morshed, M.; Nasr-Esfahani, M.H.; Ramakrishna, S. Electrical Stimulation of Nerve Cells Using Conductive Nanofibrous Scaffolds for Nerve Tissue Engineering. Tissue Eng. Part A 2009, 15, 3605-3619. [CrossRef]

29. Huang, L.; Zhuang, X.; Hu, J.; Lang, L.; Zhang, P.; Wang, Y.; Chen, X.; Wei, Y.; Jing, X. Synthesis of Biodegradable and Electroactive Multiblock Polylactide and Aniline Pentamer Copolymer for Tissue Engineering Applications. Biomacromolecules 2008, 9, 850-858. [CrossRef]

30. Zhang, Q.-S.; Yan, Y.-H.; Li, S.-P.; Feng, T. Synthesis of a novel biodegradable and electroactive polyphosphazene for biomedical application. Biomed. Mater. 2009, 4, 035008. [CrossRef]

31. Guo, Y.; Li, M.; Mylonakis, A.; Han, J.; MacDiarmid, A.G.; Chen, X.; Lelkes, P.I.; Wei, Y. Electroactive Oligoaniline-Containing Self-Assembled Monolayers for Tissue Engineering Applications. Biomacromolecules 2007, 8, 3025-3034. [CrossRef] [PubMed]

32. Humpolicek, P.; Kasparkova, V.; Saha, P.; Stejskal, J. Biocompatibility of polyaniline. Synth. Met. 2012, 162, 722-727. [CrossRef]

33. Cullen, D.K.; RPatel, A.; Doorish, J.F.; Smith, D.H.; Pfister, B.J. Developing a tissue-engineered neural-electrical relay using encapsulated neuronal constructs on conducting polymer fibers. J. Neural Eng. 2008, 5, 374-384. [CrossRef]

34. Borriello, A.; Guarino, V.; Schiavo, L.; Alvarez-Perez, M.A.; Ambrosio, L. Optimizing PANi doped electroactive substrates as patches for the regeneration of cardiac muscle. J. Mater. Sci. Mater. Med. 2011, 22, 1053-1062. [CrossRef]

35. Guarino, V.; Alvarez-Perez, M.A.; Borriello, A.; Napolitano, T.; Ambrosio, L. Conductive PANi/PEGDA Macroporous Hydrogels for Nerve Regeneration. Adv. Healthc. Mater. 2013, 2, 218-227. [CrossRef] [PubMed]

36. Gizdavic-Nikolaidis, M.; Ray, S.; Bennett, J.R.; Easteal, A.J.; Cooney, R.P. Electrospun Functionalized Polyaniline Copolymer-Based Nanofibers with Potential Application in Tissue Engineering. Macromol. Biosci. 2010, 10, 1424-1431. [CrossRef]

37. McKeon, K.D.; Lewis, A.; Freeman, J.W. Electrospun poly (D, L-lactide) and polyaniline scaffold characterisation. J. Appl. Polym. Sci. 2010, 115, 1566-1572. [CrossRef] 
38. Ostrovidov, S.; Ebrahimi, M.; Bae, H.; Nguyen, H.K.; Salehi, S.; Kim, S.B.; Kumatani, A.; Matsue, T.; Nakajima, K.; Hidema, S.; et al. Gelatin-Polyaniline Composite Nanofibers Enhanced Excitation-Contraction Coupling System Maturation in Myotubes. ACS Appl. Mater. Interfaces 2017, 9, 42444-42458. [CrossRef]

39. Li, L.; Ge, J.; Guo, B.; Ma, P.X. In situ forming biodegradable electroactive hydrogels. Polym. Chem. 2014, 5, 2880-2890. [CrossRef]

40. Li, L.; Ge, J.; Ma, P.X.; Guo, B. Injectable conducting interpenetrating polymer network hydrogels from gelatin-graft-polyaniline and oxidized dextran with enhanced mechanical properties. RSC Adv. 2015, 5, 92490-92498. [CrossRef]

41. Chen, J.; Yu, M.; Guo, B.; Ma, P.X.; Yin, Z. Conductive nanofibrous composite scaffolds based on in-situ formed polyaniline nanoparticle and polylactide for bone regeneration. J. Colloid Interface Sci. 2018, 514, 517-527. [CrossRef] [PubMed]

42. Ding, H.; Zhong, M.; Kim, Y.J.; Pholpabu, P.; Balasubramanian, A.; Hui, C.M.; He, H.; Yang, H.; Matyjaszewski, K.; Bettinger, C.J. Biologically Derived Soft Conducting Hydrogels Using Heparin-Doped Polymer Networks. ACS Nano 2014, 8, 4348-4357. [CrossRef] [PubMed]

43. Dong, R.; Zhao, X.; Guo, B.; Ma, P.X. Self-Healing Conductive Injectable Hydrogels with Antibacterial Activity as Cell Delivery Carrier for Cardiac Cell Therapy. ACS Appl. Mater. Interfaces 2016, 8, 17138-17150. [CrossRef] [PubMed]

44. Wang, L.; Wu, Y.; Guo, B.; Ma, P.X. Nanofiber Yarn/Hydrogel Core-Shell Scaffolds Mimicking Native Skeletal Muscle Tissue for Guiding 3D Myoblast Alignment, Elongation, and Differentiation. ACS Nano 2015, 9, 9167-9179. [CrossRef] [PubMed]

45. Arioz, I.; Erol, O.; Bakan, G.; Dikecoglu, F.B.; Topal, A.E.; Urel, M.; Dana, A.; Tekinay, A.B.; Guler, M.O. Biocompatible Electroactive Tetra(aniline)-Conjugated Peptide Nanofibers for Neural Differentiation. ACS Appl. Mater. Interfaces 2018, 10, 308-317. [CrossRef] [PubMed]

46. Guex, A.G.; Spicer, C.D.; Armgarth, A.; Gelmi, A.; Humphrey, E.J.; Terracciano, C.M.; Harding, S.E.; Stevens, M.M. Electrospun aniline-tetramer-co-polycaprolactone fibers for conductive, biodegradable scaffolds. Mrs Commun. 2017, 7, 375-382. [CrossRef]

47. Vyas, C.; Poologasundarampillai, G.; Hoyland, J.; Bartolo, P. 12-3D printing of biocomposites for osteochondral tissue engineering. In Biomedical Composites, 2nd ed.; Ambrosio, L., Ed.; Woodhead Publishing: Cambridge, UK, 2017; pp. 261-302.

48. Midha, S.; Dalela, M.; Sybil, D.; Patra, P.; Mohanty, S. Advances in three-dimensional bioprinting of bone: Progress and challenges. J. Tissue Eng. Regen. Med. 2019, 13, 925-945. [CrossRef]

49. Vyas, C.; Pereira, R.; Huang, B.; Liu, F.; Wang, W.; Bartolo, P. Engineering the vasculature with additive manufacturing. Curr. Opin. Biomed. Eng. 2017, 2, 1-13. [CrossRef]

50. Lee, S.-J.; Esworthy, T.; Stake, S.; Miao, S.; Zuo, Y.Y.; Harris, B.T. Advances in 3D Bioprinting for Neural Tissue Engineering. Adv. Biosyst. 2018, 2, 1700213. [CrossRef]

51. Melchels, F.P.W.; Domingos, M.A.N.; Klein, T.J.; Malda, J.; Bartolo, P.J.; Hutmacher, D.W. Additive manufacturing of tissues and organs. Prog. Polym. Sci. 2012, 37, 1079-1104. [CrossRef]

52. Stejskal, J.; Gilbert, R.G. Polyaniline. Preparation of a conducting polymer (IUPAC Technical Report). Pure Appl. Chem. 2002, 74, 857-867. [CrossRef]

53. Abu-Thabit, N.Y. Chemical Oxidative Polymerization of Polyaniline: A Practical Approach for Preparation of Smart Conductive Textiles. J. Chem. Educ. 2016, 93, 1606-1611. [CrossRef]

54. Wu, J.C.-C.; Ray, S.; Gizdavic-Nikolaidis, M.; Uy, B.; Swift, S.; Jin, J. Nanostructured bioactive material based on polycaprolactone and polyaniline fiber-scaffolds. Synth. Met. 2014, 198, 41-50. [CrossRef]

55. Schindelin, J.; Arganda-Carreras, I.; Frise, E.; Kaynig, V.; Longair, M.; Pietzsch, T. Fiji: An open-source platform for biological-image analysis. Nat. Methods. 2012, 9, 676. [CrossRef] [PubMed]

56. Domingos, M.; Intranuovo, F.; Russo, T.; De Santis, R.; Gloria, A.; Ambrosio, L. The first systematic analysis of 3D rapid prototyped poly(epsilon-caprolactone) scaffolds manufactured through BioCell printing: The effect of pore size and geometry on compressive mechanical behaviour and in vitro hMSC viability. Biofabrication 2013, 5, 045004. [CrossRef] [PubMed]

57. Loh, Q.L.; Choong, C. Three-dimensional scaffolds for tissue engineering applications: Role of porosity and pore size. Tissue Eng. Part B Rev. 2013, 19, 485-502. [CrossRef]

58. International Organization for Standardization. Rigid Cellular Plastics-Determination of Compression Properties; International Organization for Standardization, ISO: Geneva, Switzerland, 2014. 
59. Sobral, J.M.; Caridade, S.G.; Sousa, R.A.; Mano, J.F.; Reis, R.L. Three-dimensional plotted scaffolds with controlled pore size gradients: Effect of scaffold geometry on mechanical performance and cell seeding efficiency. Acta Biomater. 2011, 7, 1009-1018. [CrossRef]

60. Zeng, F.; Qin, Z.; Liang, B.; Li, T.; Liu, N.; Zhu, M. Polyaniline nanostructures tuning with oxidants in interfacial polymerization system. Prog. Nat. Sci. Mater. Int. 2015, 25, 512-519. [CrossRef]

61. Lee, K.; Cho, S.; Heum Park, S.; Heeger, A.J.; Lee, C.-W.; Lee, S.-H. Metallic transport in polyaniline. Nature 2006, 441, 65-68. [CrossRef]

62. Zhou, H.H.; Wen, J.B.; Ning, X.H.; Fu, C.P.; Chen, J.H.; Kuang, Y.F. Comparison of the growth process and electrochemical properties of polyaniline films prepared by pulse potentiostatic and potentiostatic method on titanium electrode. J. Appl. Polym. Sci. 2007, 104, 458-463. [CrossRef]

63. Murphy, C.M.; Haugh, M.G.; O'Brien, F.J. The effect of mean pore size on cell attachment, proliferation and migration in collagen-glycosaminoglycan scaffolds for bone tissue engineering. Biomaterials 2010, 31, 461-466. [CrossRef] [PubMed]

64. O’Brien, F.J.; Harley, B.A.; Yannas, I.V.; Gibson, L.J. The effect of pore size on cell adhesion in collagen-GAG scaffolds. Biomaterials 2005, 26, 433-441. [CrossRef] [PubMed]

65. Karageorgiou, V.; Kaplan, D. Porosity of 3D biomaterial scaffolds and osteogenesis. Biomaterials 2005, 26, 5474-5491. [CrossRef] [PubMed]

66. Mitra, J.; Tripathi, G.; Sharma, A.; Basu, B. Scaffolds for bone tissue engineering: Role of surface patterning on osteoblast response. RSC Adv. 2013, 3, 11073-11094. [CrossRef]

67. Boyan, B.D.; Lotz, E.M.; Schwartz, Z. Roughness and Hydrophilicity as Osteogenic Biomimetic Surface Properties. Tissue Eng. Part A 2017, 23, 1479-1489. [CrossRef]

68. Menzies, K.L.; Jones, L. The impact of contact angle on the biocompatibility of biomaterials. Optom. Vis. Sci. 2010, 87, 387-399. [CrossRef]

69. Deligöz, H. Preparation of self-standing polyaniline-based membranes: Doping effect on the selective ion separation and reverse osmosis properties. J. Appl. Polym. Sci. 2007, 105, 2640-2645. [CrossRef]

70. Sarvari, R.; Akbari-Alanjaraghi, M.; Massoumi, B.; Beygi-Khosrowshahi, Y.; Agbolaghi, S. Conductive and biodegradable scaffolds based on a five-arm and functionalized star-like polyaniline-polycaprolactone copolymer with a d-glucose core. New J. Chem. 2017, 41, 6371-6384. [CrossRef]

71. Huang, B.; Bartolo, P.J. Rheological Characterisation of Polymer/ceramic blends for 3D printing of bone scaffolds. Polym. Test. 2018, 68, 365-378. [CrossRef]

72. Rosales-Leal, J.I.; Rodríguez-Valverde, M.A.; Mazzaglia, G.; Ramón-Torregrosa, P.J.; Díaz-Rodríguez, L.; García-Martínez, O.; Vallecillo-Capilla, M.; Ruiz, C.; Cabrerizo-Vílchez, M.A. Effect of roughness, wettability and morphology of engineered titanium surfaces on osteoblast-like cell adhesion. Colloids Surf. A Physicochem. Eng. Asp. 2010, 365, 222-229. [CrossRef]

73. Gibson, L.J. Biomechanics of cellular solids. J. Biomech. 2005, 38, 377-399. [CrossRef] [PubMed]

74. Martin, R.B.; Burr, D.B.; Sharkey, N.A.; Fyhrie, D.P. Mechanical Properties of Bone. In Skeletal Tissue Mechanics; Martin, R.B., Burr, D.B., Sharkey, N.A., Fyhrie, D.P., Eds.; Springer: New York, NY, USA, 2015; pp. $355-422$.

75. Oftadeh, R.; Perez-Viloria, M.; Villa-Camacho, J.C.; Vaziri, A.; Nazarian, A. Biomechanics and Mechanobiology of Trabecular Bone: A Review. J. Biomech. Eng. 2015, 137, 010802. [CrossRef] [PubMed]

76. Saha, S.; Williams, P.A. Comparison of the electrical and dielectric behavior of wet human cortical and cancellous bone tissue from the distal tibia. J. Orthop. Res. 1995, 13, 524-532. [CrossRef] [PubMed]

77. Mahat, M.M.; Mawad, D.; Nelson, G.W.; Fearn, S.; Palgrave, R.G.; Payne, D.J.; Stevens, M.M. Elucidating the deprotonation of polyaniline films by X-ray photoelectron spectroscopy. J. Mater. Chem. C 2015, 3, 7180-7186. [CrossRef]

78. Li, Y.; Li, X.; Zhao, R.; Wang, C.; Qiu, F.; Sun, B.; Ji, H.; Qiu, J.; Wang, C. Enhanced adhesion and proliferation of human umbilical vein endothelial cells on conductive PANI-PCL fiber scaffold by electrical stimulation. Mater. Sci. Eng. C 2017, 72, 106-112. [CrossRef]

(C) 2020 by the authors. Licensee MDPI, Basel, Switzerland. This article is an open access article distributed under the terms and conditions of the Creative Commons Attribution (CC BY) license (http://creativecommons.org/licenses/by/4.0/). 